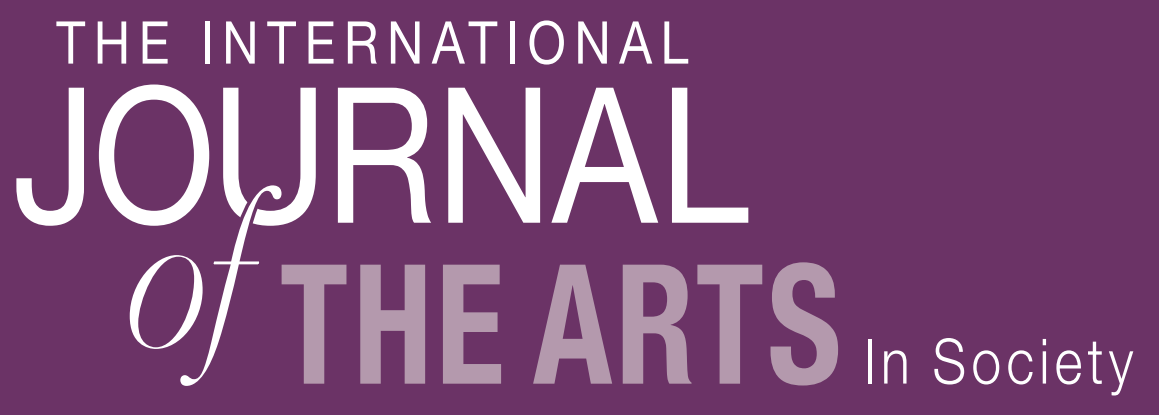

Volume 5, Number 6

Walking in the World of Ruins: Explorations in the Products and Processes of Autobiographical Fiction

Ursula Hurley 
THE INTERNATIONAL JOURNAL OF THE ARTS IN SOCIETY

http://www.arts-journal.com

First published in 2011 in Champaign, Illinois, USA

by Common Ground Publishing LLC

www.CommonGroundPublishing.com

ISSN: $1833-1866$

(C) 2011 (individual papers), the author(s)

(c) 2011 (selection and editorial matter) Common Ground

All rights reserved. Apart from fair dealing for the purposes of study, research, criticism or review as permitted under the applicable copyright legislation, no part of this work may be reproduced by any process without written permission from the publisher. For permissions and other inquiries, please contact

<cg-support@commongroundpublishing.com>.

THE INTERNATIONAL JOURNAL OF THE ARTS IN SOCIETY is peer-reviewed, supported by rigorous processes of criterion-referenced article ranking and qualitative commentary, ensuring that only intellectual work of the greatest substance and highest significance is published.

Typeset in Common Ground Markup Language using CGPublisher multichannel typesetting system

http://www.commongroundpublishing.com/software/ 


\title{
Walking in the World of Ruins: Explorations in the Products and Processes of Autobiographical Fiction
}

\author{
Ursula Hurley, University of Salford, Greater Manchester, UK
}

\begin{abstract}
I continue his [Sebald's] walks in the world of ruins, of what is dead. I continue his contact with a stimulating tendency of the contemporary novel, a tendency that opens new ground in between essay, fiction and autobiography... So writes Enrique Vila-Matas in his innovative text, Montano. In attempting to map this new ground, the processes and products of autobiographical fictions will be scrutinised with particular reference to questions of authenticity and voice, drawing examples from texts including James Frey's A Million Little Pieces, which problematise genre boundaries, question the relationship between reader and author, and demonstrate how life experience now, literally, has a price. The paper will conclude by proposing the first steps towards a reading and writing practice where, in the words of Goldberg, 'every page trembles, vulnerable to manifold incursions - of prior texts, of future accidents, of reading and writing'. References: Frey, James. A Million Little Pieces. (London, 2004) Goldberg, Jonathan. Voice Terminal Echo. (New York, 1986) p. 7 Vila-Matas, Enrique. Trans. Jonathan Dunne. Montano (London, 2007) p.191
\end{abstract}

Keywords: Autobiographical Fiction, Emergent Genres, Creative Processes, Creative Products, Authenticity and Voice

I

N ENRIQUE VILA-MATAS' innovative text, Montano, the narrator plays games with his readers, luring us into constructs of intimate diaries and memoirs, lecture notes and travelogues as he tries to deal with his 'malady', which is that he cannot distinguish between real life and fictional reality, and cannot write anything without reference to the works and lives of other writers. One of the issues that Montano addresses is what Jonathan Goldberg identifies as the 'critical fiction' which occurs when we assume 'that texts offer voice unmediated by textual relay'. It is not possible for authors to speak as themselves, even if they make the attempt. They will always remain 'a figure of speech presenting a speaking figure'. ${ }^{1}$ Montano grapples with this phenomenon by dramatising the difficulty of finding a voice, of presenting a subjectivity that is able to tell its own story. The creation of a composite identity, assembled from a patchwork of pre-existing texts, is presented as a potential solution to the paradox of self-narration:

I propose to work away discreetly inside the diaries of others and enlist their collaboration in the reconstruction of my precarious autobiography, which naturally, fragmented or not, will be presented as split like my personality, which is plural and ambiguous and hybrid and is basically a combination of experiences (mine and others') and reading matter. $^{2}$

\footnotetext{
${ }^{1}$ Jonathan Goldberg, Voice Terminal Echo, Postmodernism and English Renaissance Texts (New York: University Paperbacks, 1986), 5.

${ }^{2}$ Enrique Vila - Matas, trans. Jonathan Dunne, Montano (London: Harvill Secker, 2007), 101.
} 
Indeed, Montano is so densely packed with quotations from other texts that it sometimes becomes difficult to identify its genre: is it an experimental novel, or a writer's commonplace book?

Vila-Matas' text enacts a quality identified by Robin Nelson when he describes the process of authors writing over each other, in continuous iterations:

Palimpsest: 'a parchment or the like from which writing has been partially erased to make room for another text'. Or with the contemporary inflection, drawing on an archaeological metaphor, a palimpsest is a multi-layered text, the traces of previous inscriptions remaining visible in the new text. ${ }^{3}$

What Nelson observes, and what Vila-Matas explores, is the possibility of interacting productively with one's literary ancestors, to find a way to live peacefully together; to seek the possibility of synthesis. In short, to wander fruitfully in the ruins that Montano describes, finding in this act of revision, of looking back, the means to progress.

Montano proposes and enacts an emergent genre, a literary form that goes some way towards addressing Goldberg's critical fiction, and which acknowledges, even thrives upon, the tensions inherent in the relationship between autobiography and fiction, a process that Montano describes as 'mixing invention and autobiography and thus creating fictional texts." The relevance and urgency of what Montano addresses is illustrated by the difficulties that authors encounter when they venture into the shifting borderlands that lie between what we understand as autobiography and what we term fiction. One of the most notable recent examples is James Frey.

In 2003, Frey's novel-length text, A Million Little Pieces was published. Although no generic label was attached to this text (the covers simply bore the author's name and the title), the intimate, confessional tone and the authentic quality of the experiences described led critics, reviewers and the reading public to identify the work as a memoir. It became a word-of-mouth success, and in the United States, A Million Little Pieces was championed by Oprah Winfrey, a powerful arbiter of public taste. It sold about 3.5 million copies before investigations into the accuracy of the narrative revealed that, in comparison with police and medical records, some events had been altered or distorted. ${ }^{5}$ This caused a national scandal. Frey was forced to issue an apology, and his publishers in the U.S. offered refunds to anyone who had bought the work assuming it to be 'true' and now found themselves dissatisfied with it because of its fictional elements. ${ }^{6}$

Disturbingly, in 2006 it was reported that:

Some readers have now decided to sue the book's publisher, Random House and the relevant subdivision, Doubleday, in three separate class action lawsuits, in Los Angeles,

\footnotetext{
${ }^{3}$ Robin Nelson, "Set Map Slip = Palimpsest (working title) - 'working' because it is provisional and 'working' because it is on the move," Performance Research 6, no.2 (2001): 20.

${ }^{4}$ Vila-Matas, 102.

5 James Frey, A Million Little Pieces (London: John Murray, 2004). The Smoking Gun, “A Million Little Lies: Exposing James Frey's Fiction Addiction." http://www.thesmokinggun.com/archive/0104061jamesfrey1.html.

${ }^{6}$ Gawker.com, http://gawker.com/news/james-frey/james-frey-settlement-website-imminent-245978.php.
} 
Illinois, and Seattle. Each suit alleges breach of contract, and negligent misrepresentation as well as consumer fraud, and each seeks millions of dollars in damages.

This situation seems to illustrate a value judgement that privileges 'truth' over all other literary merits. It implies that works such as Frey's, which deviate from journalistic standards of accuracy in order to serve 'the greater purpose of the book,' are quite literally worthless and may in fact be harmful to readers. ${ }^{8}$

A Million Little Pieces is the story of Frey's descent into and salvation from drug and alcohol abuse. At one point he tells of his arrest for a serious offence. An investigator checked the police records and found a less serious offence had been recorded. Frey writes viscerally about dental treatment without pain relief (he believes he was denied narcotics because of his addiction). A dentist takes his account to pieces, quibbling with Frey's descriptions of various pieces of specialist equipment. ${ }^{9}$ Rubbishing Frey's book became a national sport. As Frey reasonably points out, his text 'is a subjective truth, altered by the mind of a recovering drug addict and alcoholic. Ultimately, it's a story, and one that I could not have written without having lived the life I've lived.' He writes of his shock and hurt at being pilloried for working 'from memory instead of from a strict journalistic or historical standard'. 'My mistake,' he confesses, 'and one I deeply regret, is writing about the person I created in my mind to help me cope, and not the person who went through the experience. ${ }^{11}$

Notwithstanding the fact that Frey's memories and perceptions will have been altered by his experiences as a recovering addict, there are those who claim that writing itself is an addiction that alters cognitive processes:

'Writing,' says Lobo Antunes, 'is like taking drugs, you start purely for pleasure and you end up organising your life around your vice like a drug addict. This is my life. Even when I suffer, I live it like a split personality: the man is suffering and the writer is considering how to use the suffering in his work. ${ }^{12}$

Most (if not all) writers seem to undergo this split, which produces a duality whereby they are simultaneously a subject experiencing reality and an observing consciousness that treats their own life as if they were method actors, using every experience as grist to the writer's mill. Furthermore, Antunes suggests that the process of writing can also alter the external events of a writer's life. Laurence Sterne identifies this phenomenon in his comic mockautobiography The Life and Opinions of Tristram Shandy:

- This is vile work. - For which reason, from the beginning of this, you see, [I] have constructed the main work and the adventitious parts of it with such intersections, and have so complicated and involved the digressive and progressive moments, one wheel

\footnotetext{
7 Anita Ramasastry, “The Lawsuits over James Frey’s 'A Million Little Pieces': Although the Author Has Conceded Fabrication, The Suits Should be Dismissed," Findlaw, 02 February 2006, http://writ.news.findlaw.com/ramasastry/20060202.html.

${ }^{8}$ Frey, v.

${ }^{9}$ Dr. Jerry Gordon, ““A Million Little Pieces’ Dental Ordeal Dubious,” The Dental Comfort Zone, http://www.dentalcomfortzone.com/template.php?aid=20.

${ }^{10}$ Frey, vii.

${ }^{11}$ Ibid., vi.

${ }^{12}$ Lobo Antunes, cited by Vila-Matas, 198.
} 
within another, that the whole machine, in general, has been kept a going; -and, what's more, it shall be kept a-going these forty years, if it pleases the fountain of health to bless me so long with life and good spirits. ${ }^{13}$

The autobiographer's difficulty, which Sterne makes fun of throughout the text, is that life keeps happening. So to be truthful, and faithful to the act of autobiography, the writer must in effect withdraw from everyday life in order to write everything down. But if writing supersedes the act of living, then the paradox is that we shall have nothing about which to write.

Some authors, like Will Self and Iain Sinclair, respond to this dilemma by manipulating their lived experiences, setting up situations with the sole intention of creating unusual events that they can write about. For example, in Walking to Hollywood, Will Self walks from his house to London's Heathrow airport, and then from Los Angeles airport to his hotel in order to generate a narrative. In London Orbital, Iain Sinclair sets out to walk around the M25 motorway which circles London, recording his perceptions and encounters as encyclopaedically as possible. ${ }^{14}$ Such activity alters external aspects of the writer's life. The writer initiates events that would not otherwise have occurred, in order to produce literature.

Not all writers find it necessary, or desirable, to manipulate their lived experiences in this way. The random events of life provide more than enough material. But for Frey and many others, producing an account of lived experiences, whether randomly encountered or carefully engineered, means seeking to form a narrative, to craft a story with which readers can engage. In this process of making sense, the memory of those experiences is altered. 'Observing reality,' writes Matthew Syed, 'alters the nature of reality. And this seems to count double when we are observing ourselves. ${ }^{15}$ Thus, even if one tried to write a scrupulously honest memoir, the result would still be fiction because, as Raymond Federman points out, 'to write, then, is to produce meaning, and not reproduce a pre-existing meaning. 16

William Zinsser, writing specifically about the act of autobiography, describes the process as follows:

Good memoirs are a careful act of construction. We like to think that an interesting life will simply fall into place on the page. It won't... Memoir writers must manufacture a text, imposing narrative order on a jumble of half-remembered events. With that feat of manipulation they arrive at a truth that is theirs alone, not quite like that of anybody else who was present at the same events. ${ }^{17}$

Given such assertions, the violent reaction against Frey's text requires further explanation. Perhaps what critics and media commentators really objected to was the money and success

\footnotetext{
${ }^{13}$ Laurence Sterne, The Life and Opinions of Tristram Shandy (London: Penguin Classics, 1985), 95. First published 1759-67, the precociously postmodern characteristics of this text were foregrounded in Michael Winterbottom's recent film, Tristram Shandy: A Cock and Bull Story (BBC Films, 2006).

${ }^{14}$ Will Self, Walking to Hollywood (London: Bloomsbury, 2010). Iain Sinclair, London Orbital (London: Penguin, 2003).

${ }^{15}$ Matthew Syed, "Can pleasure exist if you know how it works?" The Times, 14th August 2010, 20.

${ }^{16}$ Raymond Federman, "Four Propositions in Form of an Introduction," in Surfiction: Fiction Now and Tomorrow, ed. Raymond Federman, 8 (Chicago: The Swallow Press Incorporated, 1975).

${ }^{17}$ William Zinsser, ed., Inventing the Truth: The Art and Craft of Memoir (New York: Mariner Books, 1998), 5-6.
} 
that a former drug addict had acquired as a result of his experiences. Perhaps there was a suspicion of Frey exaggerating for financial gain. Some readers felt that Frey's admission of deviation from recorded facts devalued the text and somehow harmed those who had used the work as a blueprint for their own salvation. Others may have been angered that Frey's publishers did nothing to correct the assumption that the text was 'true' in an externally verifiable, journalistic sense. The underlying hostility seems to stem from a notion of Frey having crossed an ethical line, whereby the writer engaged in a sincere attempt to retell his story as accurately as possible may be allowed an occasional unintentional lapse, but the writer who knowingly manipulates the truth to make his text more dramatic and therefore more saleable, cannot be forgiven.

We can never know whether Frey cynically exaggerated his experiences to give his book a better chance of succeeding commercially, or whether he was engaged in a genuine attempt to narrate his life story. On CNN's Larry King Live, an entire programme was given over to interviewing Frey. At one point King asks why Frey originally tried to sell his manuscript as a novel, when he now claims that it is essentially non-fiction. ${ }^{18}$ Frey answered as follows (my emphasis):

I mean, it's a classification of non-fiction. Some people think it's creative non-fiction. It's generally recognized that the writer of a memoir is retailing [sic] a subjective story. That it's one person's event. I mean, I still stand by the essential truths of the book... In the memoir genre, the writer generally takes liberties. You know, you take liberties with time because you're compressing time a lot. You take liberties with events and sequence of events. The important aspect of a memoir is to get at the essential truth of it... I don't think it's fair to classify this "Million Little Pieces" as fiction at all. It's a memoir. A very small portion is in dispute. ${ }^{19}$

Of particular interest here is the slip where Frey means to say 'the writer of memoir is retelling a subjective story.' Whether the slip was Frey's or the transcriber's, it shows with delicious irony just how difficult it is to record a definitive version of events. To record Frey as talking about 'retailing a subjective story' is unfortunate, given the objections that some have voiced to Frey's commercial gains on the back of a story that may not be verifiably 'true'. It is also indicative of the commodification of lived experience that we are witnessing at this moment in popular culture. Such privileging of authenticity (or, more accurately, author-centricity) is reflected in the recent commercial success of supposed autobiographies, notably Dave Pelzer's A Child Called It, that have since been declared to contain a large element of 'fiction.' The public appetite for so-called misery memoirs was noted by the New York Times: '[the] veracity of his story has come into question and Pelzer's brother has denied abuse, but Pelzer's fans apparently want to believe him because they want to believe startling recovery from horrors he describes. ${ }^{, 20}$ The narration of 'true' events seems to be prized as a commercial

\footnotetext{
18 'According to a February 2003 New York Observer story by Joe Hagan, Frey originally tried to sell the book as a fictional work, but the Talese imprint "declined to publish it as such"”. The Smoking Gun, http://www.thesmokinggun.com/archive/0104061jamesfrey1.html.

${ }^{19}$ CNN, "Larry King Live," Aired January 11, 2006 - 21:00 ET, http://transcripts.cnn.com/TRANSCRIPTS/0601/11/lk1.01.html

${ }^{20}$ Dave Pelzer, $A$ Child Called It (London: Orion, 2002).

Pat Jordan, "Dysfunction for Dollars," New York Times, 28th July, 2002, Late Edition - Final, Section 6, 22.
} 
and even moral asset of more value than those works that label themselves as 'fiction'. In the words of Deborah Orr writing in UK newspaper The Independent, 'the power of deed rather than word has acquired a rather sinister upper hand. ${ }^{21}$

Literary fiction is being eclipsed by what is awkwardly termed 'creative non-fiction'. A genre which is, according to Lee Gutkind, 'becoming the most important and popular genre in the literary world today. ${ }^{, 22}$ Despite the popularity of texts that are classified as such, creative non-fiction is an unsatisfactory term. It is, as Elizabeth Reeder points out, 'a weak definition, one that opens up the field to a lot of attacks within the fiction/non-fiction debate, debates about truth fact detail imagination ethics ideas and rights of authors. ${ }^{23}$ It encourages a horizon of expectation in the reader that the text can never fulfil: it emphasises its nonfictional status and yet 'when it uses the approaches and techniques of creative writing it will naturally move towards or enter into partially fictional realms, rendering the naming more or less meaningless. 24

The idea of 'creative non-fiction' becomes even less satisfactory when we consider the role that memory plays in autobiography and memoir. Life-writers construct versions of their past selves who don't exist any more, and perhaps never did. Thus it becomes increasingly difficult to pinpoint the border between what we class as autobiography and what we class as fiction in terms of the creative processes involved. This movement into the porous borderlands of fiction is what Paul Auster describes when he talks of memory as a voice in his mind that 'wilfully distorts the story it is telling him, changing facts to suit its whims, catering to the interests of drama rather than truth. ${ }^{, 25}$ If we wish to tell the story of our own lives in the form of a memoir with a coherent trajectory for the subject, then we must embellish, edit, and filter. We have no choice but to move, on some level, towards fiction. This is the act of telling our story. Vivian Gornick describes this moment of realisation:

[A] useful point of view, one that would permit greater freedom of association... had to be brought along. What I didn't see, and that for a long while, was that this point of view could only emerge from a narrator who was me and at the same time not me. ${ }^{26}$

Which brings us back to the splitting of subjectivity that Antunes describes. Where the literal events of a life are disjointed, random, boring or illogical, the autobiographer requires a degree of licence in order to create a satisfying, emotionally engaging narrative arc in which readers can invest. Gunnthorunn Gudmundsdottir follows Auster's line of argument to its logical conclusion: if we reconstruct the past in order to make sense of it, we have distorted it. 'For Auster, then, creating such a pattern of a life in autobiographical writing would only be an illusion as it would move to the level of fiction. ${ }^{27}$

\footnotetext{
${ }^{21}$ Deborah Orr, "The literary world's obsession with sensational 'memoirs' degrades us." The Independent, 9th September 2006, http://comment.independent.co.uk/columnists_m_z/deborah_orr/article1431118.ece

22 Lee Gutkind, The Art of Creative Nonfiction: Writing and Selling the Literature of Reality (Wiley Books for Writers, 1997) 8.

${ }^{23}$ Elizabeth Reeder, Plenary Address, "Determining Form: Creative Non-Fiction Journeys," 11th - 12th June 2010, University of Glasgow, UK.

24 Ibid.

${ }^{25}$ Paul Auster, The Invention of Solitude (London: Faber and Faber, 1988), 124.

${ }^{26}$ Vivian Gornick, The Situation and the Story (New York: Farrar Straus Giroux, 2002), 22.

${ }^{27}$ Gunnthorunn Gudmundsdottir, Borderlines: Autobiography and Fiction in Postmodern Life Writing (Postmodern Studies) (Amsterdam: Editions Rodopi B.V., 2003), 29.
} 
If we accept Auster's argument, then we also accept that autobiography is by its nature a type of fiction. Marjorie Garber reminds us: 'that biography - and, even more, autobiography - is a species of fiction-making is a truth so old that only a willed cultural amnesia can make it new. ${ }^{28}$ And yet such cultural amnesia is precisely what Laura Browder berates the reading public for. Frey, she says, took advantage of the stereotypical image of the drug addict, as conceptualised by the white middle classes: 'Readers usually prefer memoirs that tell them what they already think they know... We love comforting fictions more than we love the truth. ${ }^{29}$ Browder goes on to touch upon the sometimes extreme change in attitude that a reader can undergo when their understanding of a text's genre changes. What somebody read and enjoyed in the knowledge that they were experiencing a sincere attempt at memoir can quickly become the cause of bitter disappointment or feelings of anger at having been deceived by deliberate fictions: 'Reading these books with the knowledge that they're fakes not only defies our expectations, but teaches us their futility. 30

I disagree that such books are fake, or futile. Frey's case demonstrates the significance of the generic labels that are attached or allowed to adhere to texts, and gives some indication of the power of this act of classification to alter 'the expectations and procedures of readers. ${ }^{31}$ Works like A Million Little Pieces delineate the borderlines of genre, and demonstrate how reader orientation towards a text can drastically alter its reception. H. Porter Abbott suggests that in moving our focus from the act of writing towards the act of reading, we can begin to understand what it is that differentiates autobiography from fiction in terms of reader expectation: 'The difference, then, between an autobiography and a novel lies not in the factuality of one and the fictiveness of the other but in the different orientations toward the text that they elicit in the reader. ${ }^{32}$ This observation may go some way towards explaining the furore surrounding Frey's text. The way in which a text is positioned (deliberately or accidentally) by the publishers, marketers and booksellers, those whom Federman terms the 'middlemen of literature', seems more important than the processes and products of writerly activity in terms of defining its genre.

Some would argue that Frey's mistake was to allow his text to be positioned as memoir, and that if he had held out for a publisher who would accept his text as a novel, a great deal of difficulty could have been avoided. It is certainly the case that some writers engaged in narratives of the self seek refuge in the capacious (some would say baggy) realm of the novel, where the expectation is in favour of fiction, and where many autobiographical works seem to reside without objection. Will Self, for example, believes that 'all fiction is psychic autobiography.' 33 And Bret Easton Ellis confides that: 'I could never be as honest about myself in a piece of nonfiction as I could in any of my novels'. ${ }^{34}$ But in my opinion such a

\footnotetext{
${ }^{28}$ Marjorie Garber, "Postmodernism and the Possibility of Biography," in The Seductions of Biography, eds. Mary Rhiel and David Suchoff, 175 (New York: Routledge, 1996).

${ }^{29}$ Laura Browder, "Fake Autobiographies: A Great American Tradition," History News Network, http://hnn.us/articles/21679.html

30 Ibid.

31 Jonathan Culler, "Towards a Theory of Non-Genre Literature," in Surfiction: Fiction Now and Tomorrow, ed. Raymond Federman, 257 (Chicago: The Swallow Press Incorporated, 1975).

${ }^{32}$ H. Porter Abbott, "Autobiography, Autography, Fiction: Groundwork for a Taxonomy of Textual Categories," New Literary History 19, no. 3, History, Critics, and Criticism: Some Inquiries (Spring, 1988): 603.

${ }^{33}$ Will Self, "Reading and Q\&A," Jackson Lecture Theatre, University of Lincoln, UK, 11 th July 2010.

${ }^{34}$ Bret Easton Ellis, Lunar Park ( London: Picador. 2005), 24.
} 
strategy serves only to reinforce the current unsatisfactory situation, where genre is frequently misused or misunderstood, sometimes with distressing consequences.

The following case illustrates the dangers of using 'the novel' as a catch-all genre. In 2000 and 2001 respectively, Bloomsbury published two texts which were positioned as novels: Sarah, and The Heart is Deceitful Above All Things. The author was identified as J.T. LeRoy. Readers decided that the texts contained clues which suggested that the narrator of these novels was in fact the author telling their own life story, and the texts were eagerly accepted as the thinly disguised autobiography of a young transgender adult who had been a child sex-worker. LeRoy became a celebrity who was courted by rock stars and Hollywood actors, and the film rights to the novels were acquired by a production company. Demand for public appearances, for the author to be physically embodied, to testify to the validity of the experiences narrated in the novels, led to a startling discovery. LeRoy was a fictional construct created by Laura Albert, a middle-aged, middle-class white woman, who had paid a relative, disguised in hat and sunglasses, to play the part. Browder's point about the middle-class appetite for the comforting fictions of what they think they know seems to be borne out once again.

When Albert was unmasked, she claimed that she had created the LeRoy persona during therapy as a way of dealing with issues in her own past. In an interview with The Paris Review, she said: 'He'd tell the story and I was the secretary who would take it down and say, OK, thank you, now I'm going to try to turn it into craft. ${ }^{35}$ Antunes' concept of the author's splitting of subjectivity is demonstrated once more. However, as well as being a source of fascination for critics and commentators, Albert suffered serious personal repercussions as a result of her literary hoax when the production company that owned the film rights to her work successfully sued her for hundreds of thousands of dollars. ${ }^{36}$ The result of this trial led the Authors' Guild to warn that 'the district court's decision which holds that Laura Albert's use of pseudonym breached the Option and Purchase Agreement, is one that will have a chilling effect upon authors wishing to exercise their right to write anonymously, ${ }^{37}$

Laura Albert's and James Frey's experiences illustrate Goldberg's 'idealizing proximity of voice and self' in action, when a narrative voice is taken to be the unmediated voice of the author. ${ }^{38}$ Neither Frey nor Albert ever claimed journalistic standards for the verifiable 'truth' of their narratives or indeed their own identities, and yet they were pilloried for crossing some kind of invisible ethical line. Readers and writers seem to be involved in a high stakes game, in which no-one is quite sure of the rules, but the penalties for breaking these unwritten codes can be harsh.

Postmodern commonplaces about the impossibility of objective truth and the instability of identity are no protection for authors who fall foul of powerful assumptions about genre and what it should or should not do. If we wish to argue that all autobiography is a form of fiction, then there are many different shades of fictions. We need to find ways of describing

\footnotetext{
${ }^{35}$ Nathaniel Rich, "Being JT LeRoy,” The Paris Review, Issue 178, Fall 2006, http://www.theparisreview.org/ viewmedia.php/prmMID/5664

36 The New York Times, “Times Topics: Laura Albert (JT LeRoy),” http://topics.nytimes.com/top/reference/ timestopics/people/a/laura_albert/index.html

${ }^{37}$ Roy Hogan, “Authors Guild to Courts: Don't Judge Laura Albert So Harshly,” Sep 29, 2008, http://www.mediabistro.com/galleycat/authors/authors_guild_to_courts_dont_judge_laura_albert so_harshly_95893.asp

${ }^{38}$ Goldberg, 12.
} 
such texts, both for the practical reason of bookshops categorising their stock, and the ethical imperative that readers' expectations are not unreasonably manipulated with, as we have seen, serious consequences for the writer involved. How can we signal to readers what genre they are reading, and how can we ensure that generic classifications create an effective horizon of expectation?

Writing one's own life as fiction was what James Frey had been condemned for: altering some of the detail found in the historical record of 'truth' (or one version of truth) in order to serve the 'greater truth' that he wished the reader to access about what it was like to live in that place at that time. We could argue that Frey and his publishers should have been much more honest and open about what they were offering the reading public. And yet the literary establishment tends to frown upon writers who, like Vila-Matas, have the audacity to play their hands so openly. There is a suspicion of vulgarity, of narcissism in an author who comes on stage and introduces themselves, rather than sneaking around behind the scenes and pulling the strings from on high. 'A novelist who takes himself as the principal subject of his novel,' writes Jane Smiley in UK newspaper The Guardian's review of Montano, 'is asking for it. 39

Vila-Matas is aware of the risks he is taking with his attempt to open new ground between fiction and autobiography. Montano does not frame the novel of the self in a positive light; although that in effect is what Montano itself enacts and proposes. Montano's narrator speaks resignedly of being 'a writer doomed possibly, sooner or later - obliged by the circumstances of the time in which I happen to live - to try his hand not at the autobiographical, but the auto-fictional genre. ${ }^{40}$ There are two points worthy of further discussion here. First, the narrator distinguishes autobiography from autofiction. Second, he feels himself forced to embark upon autofiction, with 'doom' being the likely result. What is autofiction, and why would a writer be doomed by undertaking to write in this genre?

Autofiction, I would argue, is the genre that better fits A Million Little Pieces, Laura Albert's texts, and Will Self's Walking to Hollywood, which one reviewer describes as pushing 'memoir to the limits of invention'. ${ }^{41}$ Autofiction has much in common with the novel, including techniques such as characterisation, voice, narrative, chronology and setting. However, autofiction qualitatively resists classification as a novel. It is too grounded in the author's presentation of their own subjectivity to pass completely into the realms of fiction. Similarly, autofiction does not fit the traditional tropes of memoir. Autofiction is something that enacts all the contradictions inherent in the term creative non-fiction. Self-fiction. A genre that emphasises the 'auto', but dispenses with the 'biographical', the thread that binds the autobiographer to external, verifiable reality and the expectations of historical evidence and journalistic standards. Autofiction makes no claims to truths beyond the horizons of the text. It is an approximation, a dramatic interpretation, based on the best information available. This attempt is cast not as a reconstruction but as a construct which aspires, through a merging of memory and writerly craft, to approach some conception of the writing self's experience. Such a text offers readers the opportunity to share impressions of other subjectivities, while signalling very clearly that such an opportunity is mediated through the author's concerns,

\footnotetext{
39 Jane Smiley, "Lessons in Literature," The Guardian, 13 January 2007, http://www.guardian.co.uk/books/2007/jan/13/featuresreviews.guardianreview18.

${ }^{40}$ Vila-Matas, 183, 204, 119.

${ }^{41}$ Amazon, "Product Description," http://www.amazon.co.uk/Walking-Hollywood-Will-Self/ $\mathrm{dp} / 0747598444 /$ ref $=$ sr_1_1? $=$ =books\&ie=UTF8\&qid=1282726465\&sr=1-1
} 
interpretations, morality, philosophy, political persuasion and social and temporal position. 'It is not just metafictional; nor is it another version of the historical novel or the non-fictional novel. ${ }^{42}$ It is a form that acknowledges, indeed celebrates, its fictional freedoms, but that makes visible its grounding in the author's subjectivity, in their sincere attempts to narrate the self, arriving at a version of the truth that is theirs alone, even if fiction has been the lever of its becoming.

Why is a writer doomed by undertaking to work in this genre? Montano articulates a feeling of inevitability, that the age of author-centricity compels the writer to use this form. That this is what they must do in order to tell their story. And perhaps the form they must use if they wish to secure a publishing contract. But also, and more importantly, James Frey and Laura Albert are both examples of what can happen when autofiction is misunderstood. And until autofiction enters the mainstream of public consciousness, until it is debated, explored and made use of as a generic term, such misunderstandings will inevitably continue to happen. The solution, therefore, lies in how we understand genre and how we make use of it.

Understood as a relative term, subject to the same forces of history and society as the texts it is supposed to classify, genre can become a useful tool which helps us to identify, describe and understand the processes and products of writing and reading. Seen as a fluid, mutable process rather than a fixed taxonomic category, it allows the kind of productive activity that John Frow describes:

what we learn, in 'doing' genre (in performing and transforming it), is the values we share or don't share with others and the means with which to challenge or defend them. Through the use of genres we learn who we are, and encounter the limits of our world. ${ }^{43}$

And in 'doing' genre, writers and publishers have the means to protect themselves, and the reading public, from unpleasant misunderstandings. In a recent conference paper, Elizabeth Reeder made a case for greater specificity in how we describe the products of our writing processes. This seems to be the only reply that a writer has to the troubling, some might argue misleading term: 'creative non-fiction'. 44

Thus I conclude with two pleas. The first is to writers and publishers: be bold, be upfront, and be specific about the products on offer. Please don't be tempted to package a text as a novel when it qualitatively resists such a classification. And don't, please don't, market a text as memoir when that opens the writer and the reader to potentially damaging consequences.

The second plea is to critics and academics: please don't sneer at writers who are trying to be honest about their products and processes. Let's get excited about texts that play on the boundaries of genre, and let's be open to the possibilities of new genres that better serve our needs. Above all, let us talk about autofiction, so that publishers and authors feel able to use the term. Out of the ruins of what is dead, of genres that no longer serve our needs, we can collectively take the first steps towards a reading and writing practice where, in the

\footnotetext{
${ }^{42}$ Linda Hutcheon, A Poetics of Postmodernism (New York: Routledge, 1988), 5.

43 John Frow, Genre (The New Critical Idiom) (Abingdon: Routledge, 2006), 144.

${ }^{44}$ Elizabeth Reeder, "Determining Form: Creative Non-Fiction Journeys," 11th - 12th June 2010, University of Glasgow, UK.
} 
words of Goldberg, 'every page trembles, vulnerable to manifold incursions - of prior texts, of future accidents, of reading and writing, 45

\section{References}

Abbott, H. Porter. "Autobiography, Autography, Fiction: Groundwork for a Taxonomy of Textual Categories." New Literary History 19, no. 3 (Spring, 1988): 597-615.

Amazon. "Product Description." http://www.amazon.co.uk/Walking-Hollywood-WillSelf/dp/0747598444/ref=sr_1_1?s=books\&ie=UTF8\&qid=1282726465\&sr=1-1

Auster, Paul. The Invention of Solitude. London: Faber, 1988.

Browder, Laura. "Fake Autobiographies: A Great American Tradition." History News Network, http://hnn.us/articles/21679.html.

CNN. "Larry King Live." Aired January 11, 2006 - 21:00 ET, http://transcripts.cnn.com/ TRANSCRIPTS/0601/11/lkl.01.html

Culler, Jonathan. "Towards a Theory of Non-Genre Literature." In Surfiction: Fiction Now and Tomorrow, edited by Raymond Federman, 255 - 262. Chicago: The Swallow Press Incorporated, 1975.

Easton Ellis, Bret. Lunar Park. London: Picador, 2005.

Federman, Raymond. "Four Propositions in Form of an Introduction." In Surfiction: Fiction Now and Tomorrow, edited by Raymond Federman, 5-18. Chicago: The Swallow Press Incorporated, 1975.

Frey, James. A Million Little Pieces. London: John Murray, 2004.

Frow, John. Genre (The New Critical Idiom). Abingdon: Routledge, 2006.

Garber, Marjorie. "Postmodernism and the Possibility of Biography." In The Seductions of Biography, edited by Mary Rhiel and David Suchoff, pp 175 - 177. New York: Routledge, 1996.

Gawker. "James Frey Settlement Website Imminent.” http://gawker.com/news/james-frey/james-freysettlement-website-imminent-245978.php.

Goldberg, Jonathan. Voice Terminal Echo, Postmodernism and English Renaissance Texts. New York: University Paperbacks, 1986.

Gordon, Jerry. “'A Million Little Pieces’ Dental Ordeal Dubious.” Dental Comfort Zone. http://www.dentalcomfortzone.com/template.php?aid=20.

Gornick,Vivian. The Situation and the Story. New York: Farrar Straus Giroux, 2002.

Gudmundsdottir, Gunnthorunn. Borderlines: Autobiography and Fiction in Postmodern Life Writing (Postmodern Studies). Amsterdam: Editions Rodopi B.V., 2003.

Gutkind, Lee. The Art of Creative Nonfiction: Writing and Selling the Literature of Reality. Hoboken: Wiley Books for Writers, 1997.

Hogan, Roy. "Authors Guild to Courts: Don't Judge Laura Albert So Harshly.” 29th September 2008. http://www.mediabistro.com/galleycat/authors/authors_guild_to_courts_dont_judge_laura_ albert_so_harshly_95893.asp

Hutcheon, Linda. A Poetics of Postmodernism. New York: Routledge, 1988.

Jordan, Pat. "Dysfunction for Dollars." New York Times, Late Edition - Final, Section 6, July 28, 2002.

LeRoy, JT. Sarah. London: Bloomsbury, 2000.

----- The Heart Is Deceitful Above All Things. London: Bloomsbury, 2001.

Nelson, Robin. "Set Map Slip = Palimpsest (working title) - 'working' because it is provisional and 'working' because it is on the move." Performance Research 6, no. 2 (Summer, 1992): 100108.

The New York Times, “Times Topics: Laura Albert (JT LeRoy)," http://topics.nytimes.com/top/ reference/timestopics/people/a/laura_albert/index.html

\footnotetext{
${ }^{45}$ Goldberg, 7.
} 
Orr, Deborah. "The Literary World's Obsession with Sensational 'Memoirs' Degrades Us.” The Independent, 9th September 2006, http://comment.independent.co.uk/columnists_m_z/ deborah_orr/article1431118.ece.

Pelzer, Dave. A Child Called It. London: Orion, 2002.

Ramasastry, Anita. “The Lawsuits over James Frey's 'A Million Little Pieces': Although the Author Has Conceded Fabrication, The Suits Should be Dismissed.” Findlaw. February 2, 2006, http://writ.news.findlaw.com/ramasastry/20060202.html.

Reeder, Elizabeth. Plenary address, "Determining Form: Creative Non-Fiction Journeys," 11th -12 th June 2010, University of Glasgow, UK.

Rich, Nathaniel. "Being JT LeRoy." The Paris Review, Issue 178, Fall 2006, $\mathrm{http}: / /$ www.theparisreview.org/viewmedia.php/prmMID/5664

Self, Will. Walking to Hollywood. London: Bloomsbury, 2010.

----- "Reading and Q\&A," Lincoln Jackson Lecture Theatre, University of Lincoln, Brayford Pool, UK, 11th July 2010.

Sinclair, Iain. London Orbital. London: Penguin, 2003.

Smiley, Jane. "Lessons in Literature." The Guardian, 13th January 2007, http://www.guardian.co.uk/books/2007/jan/13/featuresreviews.guardianreview18.

The Smoking Gun, “A Million Little Lies: Exposing James Frey's Fiction Addiction.” $\mathrm{http}: / /$ www.thesmokinggun.com/archive/0104061jamesfrey1.html.

Sterne, Laurence. The Life and Opinions of Tristram Shandy, Gentleman. London: Penguin Classics, 1985.

Syed, Matthew. "Can pleasure exist if you know how it works?" The Times, 14th August 2010, 20.

Vila-Matas, Enrique. Montano. Translated by Jonathan Dunne. London: Harvill Secker, 2007.

Zinsser, William, ed. Inventing the Truth: The Art and Craft of Memoir. New York: Mariner Books, 1998.

\section{About the Author}

Dr. Ursula Hurley

Ursula Hurley teaches Creative Writing and English Literature at the University of Salford. An award winning writer, she works in poetry, creative non-fiction and experimental prose fiction. She has recently published her first poetry collection, Tree, with Erbacce Press (http://erbacce-press.com/\#/ursula-hurley/4535837556), and her first novel is forthcoming. She was shortlisted for the Impress Prize for New Writers 2008 (creative non-fiction), and the Gloom Cupboard International Poetry Prize. She has delivered workshops for the Writer's Handbook LIVE (London) and for The Times Literature Festival, Cheltenham, UK. 


\section{JOÜRNALA f THE ARTS WI SOClEIY}

\section{EDITORS}

Mary Kalantzis, University of Illinois, Urbana-Champaign, USA.

Bill Cope, University of Illinois, Urbana-Champaign, USA.

\section{EDITORIAL ADVISORY BOARD}

Caroline Archer, UK Type, Birmingham, UK.

Robyn Archer, Performer and Director, Paddington, Australia.

Mark Bauerlein, National Endowment for the Arts, Washington, D.C., USA.

Tressa Berman, BorderZone Arts, Inc., San Francisco, USA; University of Technology, Sydney, Australia; California College of the Arts, San Francisco, USA.

Judy Chicago, Artist and Author, New Mexico, USA.

Bill Cope, University of Illinois, Urbana-Champaign, USA.

Nina Czegledy, University of Toronto, Toronto, Canada; Concordia University, Montreal, Canada. James Early, Smithsonian Institution, Washington, D.C., USA.

Mehdi Faridzadeh, International Society for Iranian Culture (ISIC), New York, USA, Tehran, Iran. Jennifer Herd, Queensland College of Art, Griffith University, Brisbane, Australia.

Fred Ho, Composer and Writer, New York, USA.

Andrew Jakubowicz, University of Technology, Sydney, Australia.

Mary Kalantzis, University of Illinois, Urbana-Champaign, USA.

Gerald McMaster, Curator, Art Gallery of Ontario, Toronto, Canada.

Mario Minichiello, Birmingham Institute of Art and Design, Birmingham, UK.

Fred Myers, New York University, New York, USA.

Darcy Nicholas, Porirua City Council, Porirua, New Zealand.

Daniela Reimann, Institute of Media in Education, University of Education, Freiburg, Germany; University of Art and Industrial Design, Linz, Austria.

Arthur Sabatini, Arizona State University, Phoenix, USA.

Cima Sedigh, Sacred Heart University, Fairfield, USA.

Peter Sellars, World Arts and Culture, University of California, Los Angeles, USA.

Ella Shohat, New York University, New York, USA.

Judy Spokes, Arts Victoria, South Melbourne, Australia.

Tonel (Antonio Eligio Fernández), Artist and Art Critic, Havana, Cuba.

Marianne Wagner-Simon, World Art Organization, Berlin, Germany.

Please visit the Journal website at http://www.Arts-Journal.com for further information about the Journal or to subscribe. 


\section{THE UNIVERSITY PRESS JOURNALS}

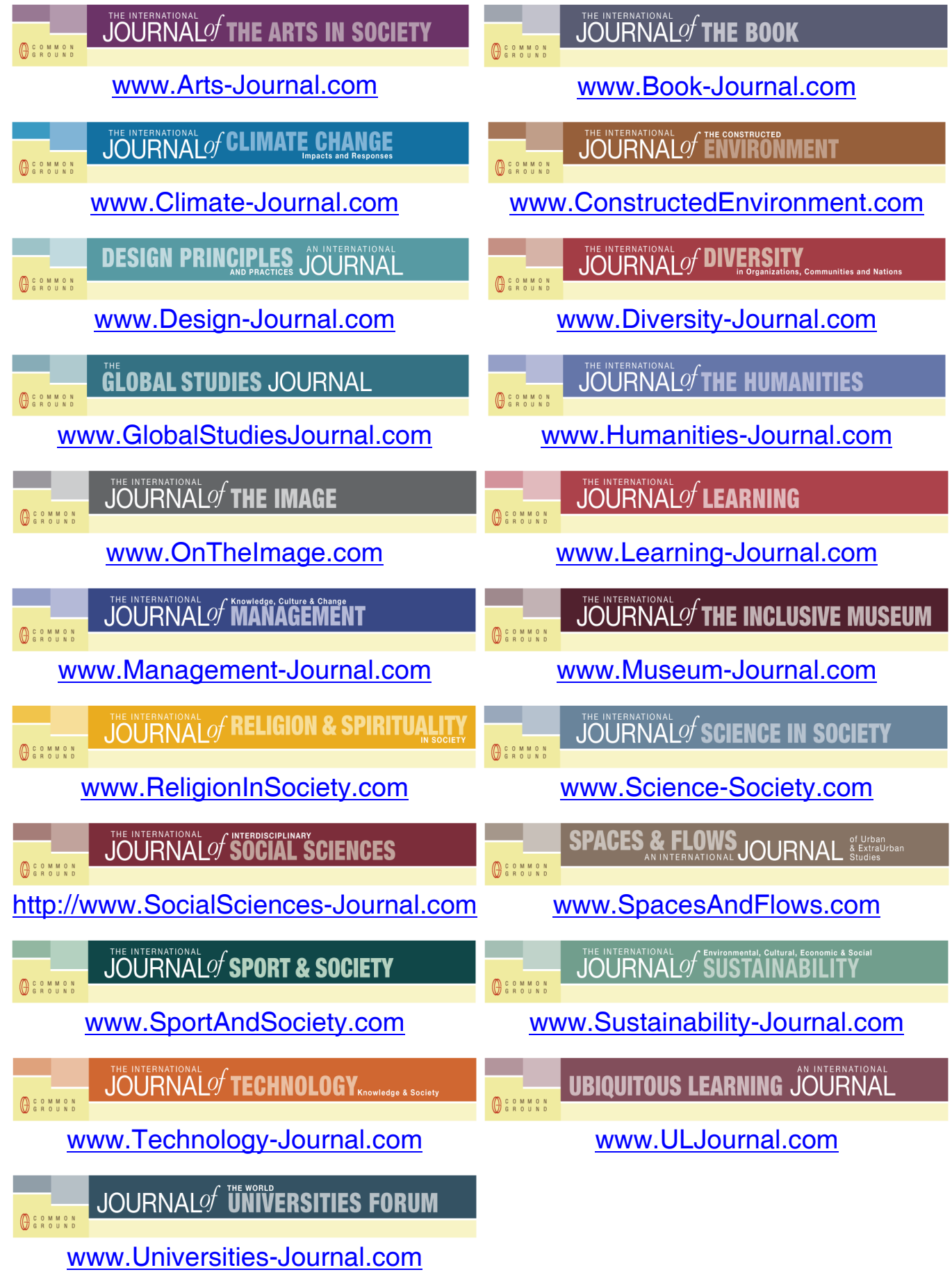

FOR SUBSCRIPTION INFORMATION, PLEASE CONTACT subscriptions@commongroundpublishing.com 